This is a pre-publication version (prior to final edit). If possible please access the final version of the article which was published as:

Robertson P.J. (2014). Health inequality and careers. British Journal of Guidance and Counselling, 42, 3, pp. 338-351.

doi: 10.1080/03069885.2014.900660 


\title{
Health inequality and careers
}

\author{
Author \\ Peter J. Robertson \\ School of Life, Sport and Social Sciences, \\ Edinburgh Napier University \\ Sighthill Campus \\ Edinburgh EH11 4BN \\ 01314556288 \\ p.robertson@napier.ac.uk
}

\begin{abstract}
Structural explanations of career choice and development are well established. Socioeconomic inequality represents a powerful factor shaping career trajectories and economic outcomes achieved by individuals. However a robust and growing body of evidence demonstrates a strong link between socio-economic inequality and health outcomes. Work is a key factor explaining differences in income and lifestyle. It seems unavoidable that inequality in careers has profound consequences for health and well-being, but this relationship is largely ignored by career scholars. Some implications of health inequality for career guidance interventions are suggested.
\end{abstract}

Key words: inequality; health; career; career guidance. 


\section{Introduction}

Health inequality represents an issue of global concern (Dorling, 2013; Lenard \& Straehle, 2012; World Health Organization, WHO 2008), and one that raises difficult issues for policy and practice. Woodward and Kawachi (2000) identify four reasons to reduce health inequality. Firstly, and most persuasively, it represents an injustice. Secondly inequalities affect everyone because there are spillover effects to the whole population (via infection or drug addiction for example). Thirdly inequalities are avoidable as they stem from identifiable public policy choices. Finally interventions to reduce health inequality are cost effective. Health inequality is therefore a topic worthy of attention.

Concern about the relationship between work and health in Britain is not new. Smith, Dorling and Shaw (2001) identify social commentary expressing concern about the health of the workers from the mid $19^{\text {th }}$ Century (notably Chadwick 1842/1965 and Engels 1845/1987). More recently there have been three landmark reports to the UK Government which highlight the extent of inequality in health: Black (1980), Acheson (1998) and Marmot (2010) ${ }^{1}$. They presented a consistent message, in terms of recognising the importance of social causation of disease, the relationship between socio-economic inequality and health outcomes, and the need for cross departmental policy remedies. However the sound knowledge base presented in these reports is necessary but not sufficient; political will is also needed for effective action (Attwood, Colditz \& Kawachi, 1997), and this has been lacking (Stoate \& Jones, 2010; Bambra, Smith, Garthwaite, \& Hunter, 2011). This is in spite of explicit recognition by the UK Government (and the devolved administrations of Scotland, Wales and Northern Ireland) of the important contribution that employment can make to health, an example being the favourable response by the Department of Work and Pensions (DWP) to Dame Carol Black's review of the health of Britain's working age population (Black, 2008; DWP, 2008).

There is strong tradition of sociological approaches that explain patterns of career choice (or lack of it) and career development in terms of structural inequality (e.g. Roberts, 1977). In addition to the work of career scholars, there is also a long history of career guidance practitioners seeking to support the most disadvantaged groups in society, indeed some of the earliest manifestations of the profession in the UK were services for young people from less privileged backgrounds (Peck, 2004). Other than a shared concern about inequity in work and education, there has been little or no crossover between the health inequality and careers literatures. This paper seeks to connect them. Specifically, it will be suggested that the contemporary British labour market tends to result in fragmented career patterns for lower socio-economic groups, and that the associated insecure lifestyles contribute to poor health outcomes. Career guidance may have a role in ameliorating the detrimental effects on health and

\footnotetext{
1 The Marmot review focuses on inequalities in England, rather than the UK as a whole.
} 
supporting individuals to navigate problematic employment environments.

The following discussion is divided into three sections. Firstly, some of the key issues and evidence identified in the health inequality literature will be highlighted. Secondly, a range of ways inequality can be conceptualised will be considered with a view to identifying the light they can shed on the links between careers and health inequality. Finally some implications for career guidance will be suggested.

\section{Health inequality: an overview}

There are socio-economic gradients in both mental and physical health, with poor outcomes associated with low income, and low social class, educational or occupational status. It is long established in epidemiology that there is incontrovertible evidence of a relationship between health inequalities and general socio-economic inequalities, and that the remaining debates relate to the details of this relationship and to the required policy responses (Gray, 1982). More recently, Marmot (2010) provided an authoritative review of evidence that links socio-economic disadvantage with poor health outcomes. This demonstrates that there are clear gradients in the relationship between deprivation and a variety of metrics of health, most strikingly life expectancy.

Extending this position, it has been persuasively argued (e.g. Bambra, 2011), that labour market structures are a key determinant of health, and this position is accepted at an international level:

“...pathways linking labour market situations to health outcomes can be identified both at the macro level and for every individual employment condition. At the macro level, we have found that there is a strong association between labour market inequality and unfavourable population health outcomes...high levels of unemployment in both societies and neighbourhoods are correlated with poor health and increased mortality." (World Health Organization, 2007, pp16 -17).

More controversially, Wilkinson (1997) and Wilkinson and Pickett $(2007 ; 2010)$ argue that in high and middle income countries (where basic needs are met) it is relative rather than absolute poverty that is important: the position on the social hierarchy seems to be a key determinant of health outcomes. ${ }^{2}$ Drawing on both international comparisons and comparisons between states within the USA, they present evidence that performance against a wide range of health and social outcomes is worse in the most unequal societies, i.e. those with the steepest status and income gradients. This

\footnotetext{
${ }^{2}$ International comparisons should not be confused with intra-national comparisons. Disease patterns may be different in low income nations, where low status is associated with malnutrition and infectious diseases, as compared to high income nations where low status is associated with diseases related to obesity, alcohol or smoking.
} 
perspective has attracted intense criticism, primarily from a neo-liberal political stance, as it could be seen to imply a policy agenda proactive in redistributing wealth. Discussion of these critiques and their rebuttal can be found at the Equality Trust (2010).

\section{Demography and geography}

Structural inequality is interwoven with demographies of diversity: gender, ethnicity, religion, age, sexuality, and disability (a construct partially overlapping with health). Whilst acknowledging the strong inter-relationship between structural inequality and diversity, it is not the focus of this paper, as space precludes giving these substantial issues the attention they merit. Here the spotlight is on social stratification. At a broad brush level, a case can be made for subsuming issues of ethnicity under the heading of socio-economic inequality. Notwithstanding the role of racism and discrimination as a source of stress,

“...a large body of convincing evidence now supports the possibility that ethnic inequalities in health are largely the consequence of socio-economic differentials. This applies in both the United States and the United Kingdom, across a range of ethnic minority groups and outcomes.” (Nazroo, 2003, p282).

Gender comparisons of health outcomes are confounded not just by biology, but by a range of social factors. As a result gender cannot be subsumed so easily within a wider consideration of status. There seems to have been fewer studies focusing on women, but counter-intuitively, some of those that do suggest health inequalities are less for women than men. This effect is not a consistent finding, but seems to be dependent on the measures of social inequality that are used (Arber, 1997; Sacker, Firth, , Fitzpatrick, Lynch \& Bartley, 2000) and also a spouse or partner's socio-economic status has an effect on women's health outcomes. Thus it is not safe to assume that women's structural disadvantage in the workplace translates to a relative disadvantage in health outcomes in comparison to men. The relative strength of family/domestic and workplace factors affecting health may differ between the genders.

Human geographers with an interest in health have clearly demonstrated that there is relationship between place and health outcomes, notably mortality, and that this maps very closely onto the geography of economic disadvantage. Relatively poor areas of the UK, i.e. those in long term economic decline, have recently faced three challenges since the economic downturn. They have proportionately bigger public sector, which has faced a reduction in funding. Poorer areas have disproportionately borne the brunt of cuts in local council funding. Reduction in welfare benefits have the greatest impact in poorer areas where relatively more people are dependent on them, and weak labour markets mean there is less chance of escaping this dependence (Dorling \& Thomas, 
2011; Lindsay \& Houston, 2011) . Furthermore some locations may become stigmatised, with negative implications for the well-being of residents (Pearce, 2012).

\section{Causal mechanisms}

Exactly how social factors 'get under the skin' to cause health problems is not fully understood, although some physiological causal mechanisms have been proposed (e.g. Sapolsky, 2005; Steptoe, 2006; Wardle \& Steptoe, 2005). In addition to diet, the most important channels to be implicated are the detrimental effects of long term exposure to stress hormones, including suppression of the immune system. Low income, insecure work and low occupational or organisational status will tend to be associated with elevated stress levels. There is robust evidence of social inequality being related to incidence of common mental health conditions (Candy, Cattell, Clark, \& Stansfeld, 2007). Several sources support the view that social factors such as poverty and inequality are the key to understanding mental health conditions (e.g. Mirosky \& Ross, 2003; Murali \& Oyebode, 2004; Rogers \& Pilgrim, 2003).

'...levels of mental distress among communities need to be understood less in terms of individual pathology and more as a response to relative deprivation and social injustice, which erode the emotional, spiritual and intellectual resources essential to psychological well-being.' (Friedli, 2009, pIII).

Mental distress, whether or not it reaches the threshold for diagnosis, may be a key channel through which social circumstances get under the skin to manifest as physical health conditions. Barnett, Mercer, Norbury, Watt, Wyke, \& Guthrie (2012) found a strong tendency for mental health disorders to co-exist with other health conditions, and that association showed a social gradient. Adults living in the most deprived areas had a prevalence of multi-morbidity the same as people 10-15 years older than them in the most affluent areas.

There remains the possibility of reverse causality: poor health may cause people to find themselves in a less favourable socio-economic situation than might otherwise be the case. This is known as "health selection' and at least one commentator (West, 1991) suggests it has been under-researched and merits more attention. Health may have detrimental effects on career by leading to educational underperformance, loss of promotion, selection for redundancy, loss of job, or reduced chance of reemployment. This raises the question of which direction of causality is most important. For at least one key population there is an answer to this question: 
"The health of men during the normal years of paid employment could directly influence their social mobility...and this is the largest group to whom selectionist arguments straightforwardly apply. Here the evidence is relatively clear cut and suggests that selection plays little part in creating class gradients in mortality. The only reasonable proviso concerns labour market entry, where the evidence suggests a minor effect." (Blane, Smith, \& Bartley 1993, p11).

Another causal factor in health inequality is that the disadvantaged receive inferior health treatment. The term 'inverse care law', introduced by Hart (1971), is used to describe the observation that the least needy get the most help from health services. This has been repeatedly demonstrated and still applies, particularly where health care has been exposed to market forces (Shaw \& Dorling, 2004).

\section{Social mobility}

Concern about social mobility in the UK was renewed with the publication of the Milburn report (The Panel on Fair Access to the Professions, 2009). Here the focus was on that sector of the community entering higher education, not on the most disadvantaged groups. This provoked some response from the guidance profession (e.g. Hughes 2010a \& b).

Social mobility does not in itself represent a solution to the problems of health inequality. Indeed Stiglitz (2013) argues that in America the (misplaced) belief in the existence of opportunities for social mobility provides a spurious justification for the tolerance of dangerously high levels of inequality. At best measures to promote social mobility may limit the extent to which social stratification becomes rigidly associated with demographic diversity. It does not necessarily reduce the extent of inequality in health outcomes. As Roberts (2005) points out, in a fixed social structure there remains limited room at the top, so facilitating upward social mobility for some also means facilitating downward social mobility for others. This activity is likely to be countered by a proactive response from the influential groups in privileged position.

Concerns about social mobility inevitably relate to the inter-generational transmission of inequality, an issue that has preoccupied some career scholars. A particular focus here is the transition from school to adult life. Landmark contributions include Willis (1977), and most particularly the work of Roberts (e.g. 1977 \&1997). The transition from school to adult life has become an extended period, less predictable, more individualised, involves greater exposure to debt, and more difficulty in entering housing markets. Furlong argues that an extended period of insecurity in transition potentially leads to increase exposure to health risks (Furlong, 2002), but he also accepts that it is possible to overstate the distinctiveness the contemporary transition experience (Furlong, 2009). 


\section{Alternative conceptualisations of inequality}

This section reviews some of the ways inequality has been conceptualised, and how these different perspectives might illuminate the links between health inequality and careers.

\section{Income inequality}

For Bambra (2011) income inequality, driven by labour market factors, is a key determinant of health outcomes. This position has a strong evidential basis. Wilkinson and Pickett (2006) reviewed 168 studies of the relationship between health outcomes and income inequality and report the great majority of them found an association.

In the 1990s, a consensus developed among economists in OECD nations that there is a trade off between levels of unemployment and the extent of wage inequality in a society (Green, 2000). This 'no pain, no gain' viewpoint explained superior economic growth and lower unemployment in the United States compared to European nations in terms of a greater tolerance for inequality (as a consequence of less regulated markets and lower levels of welfare benefits). This view continues to be influential, in spite of powerful critiques from economists such as Stiglitz (2013), who characterises the neo-liberal consensus as a 'free market fundamentalism'. He argues that unregulated markets have failed to maximise wealth creation, but instead create unequal societies that concentrate wealth in a very small minority, a process facilitated by globalisation and one that has accelerated since the onset of the global economic downturn.

Stuckler and Basu (2013) support and extend this position by linking it to population health. Based on extensive international analysis of health outcomes in historic and recent recessions, they present evidence that where governments have chosen austerity measures as a policy response (as opposed to economic stimulus) this has not only been ineffective, it has also been detrimental to population health. Income inequality is central to this process. These sources are unambiguously critical of the UK Coalition Government's austerity based response to recession.

\section{Organisational status}

Organisations acting as employers are status hierarchies, and gradients of health inequality can be found within them. This is easier to detect in large employers, and was clearly demonstrated by studies of the British Civil Service. Although predominantly a 'white collar' office environment, this was an ideal setting to explore the health effects of hierarchy, as it offered both very large spread of status, from the highest mandarin to the most humble office messenger, and a range of fine gradations in between. A large scale, prospective longitudinal study, known as 'Whitehall I' demonstrated a clear link between lower status and greater susceptibility to coronary heart disease, and also a smooth 
gradient in associated risk factors throughout the hierarchy (Marmot, Rose, Shipley \& Hamilton, 1978). The 'Whitehall II' study (Stansfeld, Fuhrer, Shipley, \& Marmot, 1999; Ferrie, Shipley, Stansfeld \& Marmot, 2002) explored psycho-social health and found an association between psychiatric symptomatology and junior status, and were able to link this to specific job characteristics, such as reduced levels of control experienced at the bottom of the status hierarchy. Karasek's (1979) 'demand-control' model was found to be useful in explaining the causal link between decision latitude and stress. Perceived unfairness was also a potential factor as it was associated with lower levels in the organisation, and those reporting it were more likely to experience a coronary event, and tended to have poor mental and physical health at follow up (De Vogli, Ferrie, Chandola, Kivimäki \& Marmot 2007).

\section{Social class and occupational status}

Defining social status in terms of occupation for purposes of government statistics has a long history in the UK. An influential classification was produced by in 1911 by the Registrar General's office (a precursor to the Office for National Statistics). Although not unproblematic, these classifications have often been adopted in sociological research (Roberts, 2005; Watson, 2008). The Marmot review (2010) unambiguously demonstrates that mortality rates that are substantially greater in lower level (routine) categories of work, and less in higher (managerial and professional) occupations. This social gradient in health outcomes is more pronounced in less wealthy parts of England.

Specific occupations attract particular risks by virtue of their nature. Armed forces personnel are potentially exposed to combat risks including death, injury disability and post-traumatic stress. Workers in the construction and extraction industries may be exposed to environmental threats and accidental injury. Certain working conditions also have health implications. Shift work for example, is known to be associated with health detriments including increased risk of cardio-vascular illness (Vyas, Garg, Iansavichus, Costella, Donner, Laugsand, Janszky, Mrkobrada, Parraga, Hackam, 2012).

Sociology has been particularly pre-occupied with special categories of work that may be perceived as of low status, 'deviant' or 'unclean' (Watson, 2008), but here health related evidence is harder to find. For example evidence relating to the hidden economy is scarce, but Šverko, Galić, Seršić \& Galšeić (2008) suggest that illegal working may offer some of the mental health benefits of legal employment. However this might be mitigated by anxiety associated with its insecurity, and an increased risk of all kinds of threats to occupational health (WHO, 2007). 


\section{Degrees of inclusion in work}

Under the Labour Government (1997-2010) the discourse of social exclusion and inclusion was used in preference to that of poverty, in spite of ambiguity about the meaning of these terms (Levitas, 1998; Roberts, 2002). Notwithstanding issues of problematic political discourse, it seems clear that workers vary not only in income and occupational or organisational status, but also in how distant they are from secure employment in a healthy job. Dooley (2003) suggests that the dichotomy between employment and unemployment is inadequate and that thinking in terms of continuum of employment status may be more useful. Shildrick, MacDonald, Webster \& Garthwaite (2012), identify a diversity of terms used to describe marginal or insecure work: 'contingent', 'non-standard', 'atypical', and 'non-traditional' being among them. A flexible labour market environment allows employers to outsource risk by use of employment contracts for contingent workers (e.g. short term, temporary or zero hours contracts).

Work that is marginal may be most accessible to the unemployed. This kind of environment may offer only partial or negligible well-being benefits over unemployment (Friedland \& Price, 2003; Broom, D’Souza, Strazdins, Butterworth, Parslow \& Rodgers, 2006; Llena-Nozal, 2009). In the UK and USA policies to promote labour market flexibility have led to a relative increase in marginal work, and there is mounting evidence of health effects of job insecurity (Bartley, Ferrie \& Montgomery, 2006). A growing disadvantaged group of workers with fragmented career patterns has been characterised as 'the precariat' by Standing (2011). Strong support for Standing's position is offered by Shildrick et al. (2012), who describe workers locked into a 'low-pay, no pay' cycle. This group may be more vulnerable to illness, but have less access to sick pay, so have to rely on welfare benefits when sick or between jobs (if they qualify for them).

\section{Educational inequality}

Education has attracted the attention of sociologists interested in status and its reproduction across generations, most notably Bourdieu, whose concept of 'cultural capital' is powerful in explaining social advantage that is not rooted exclusively in economic power (Giddens, 2009). His notion of 'habitus' refers to learnt and self-perpetuating patterns of perception, thought and action which represent an internalisation of the social structure (Calhoun, 2000). To the extent that habitus is shared it can be seen as a lifestyle for a particular class or social group. It follows that habitus might offer an abstract conceptual view of how 'social structure gets under the skin' in a way that complements psycho-biological explanations.

Although lifestyle must have health implications, this line of reasoning is not well developed in Bourdieu's work. Rather, attempts to capture the role of education in health inequality have relied on 
empirical correlational studies. The findings of research in this field can be briefly summarised thus: "People with more education typically live longer and healthier lives" (Muenning, 2007, 125). There is good evidence that more years spent in education result in improved health outcomes across a range of different measures (Centre for Research into the Wider Benefits of Learning, 2006; Hammond, 2004; Ross \& Mirowsky, 1999). However this evidence base is not unproblematic. Those who drop out of courses are usually excluded from samples. Reverse causality and health selection effects cannot be ruled out. Education may produce a number of disbenefits, including assessment related stress, unfulfilled expectations, or the weakening of family social ties: these are rarely captured by the research. It may be that some of the observed effects of education on health can be explained by underlying third factors such as income.

\section{Some implications for career guidance}

The issue of health inequality raises a number of uncomfortable questions for the career guidance profession. These include the following:

\section{Does career information and guidance adequately address health risks?}

Career advisers are coy about directly discussing issues of social status. There are two main reasons for this. Firstly, it is both pragmatic and ethical to respect all clients' occupational interests. Some low status occupations provide a vital function in society; indeed Shildrick et al. (2012) suggest that the low pay contingent workforce has become essential to the structure of the economy. Secondly, the substantial influence of psychology on career guidance directs attention towards individual rather than structural factors:

\footnotetext{
"It should be no surprise, therefore, that the theories, which simultaneously serve as professional ideologies, which career guidance professionals have embraced, have consistently erased class from their fields of vision." (Roberts, 2005, p138).
}

Similarly career information rarely attempts to give systematic warnings about the potential health implications of choosing a specific occupation, even though such information could probably be constructed from published research, and government statistics or actuarial data sets. The existence of a demonstrable link between longevity and work presents a moral challenge to the career guidance community to reconsider this tradition of presenting all occupations as different but equal; they are not. In some occupations, chiefly lower status ones, individuals are likely to enjoy fewer (disability free) years of life than in others. There is no guarantee that clients would attend to, or act on such information, but it could be argued that they have a right to it. 
2. Does the inverse care law apply to career guidance services?

The most socially disadvantaged should receive the best, not the worst careers services. Adult workers in the low-pay, no pay cycle may be the target of government policies which tend to propel them rapidly from unemployment into marginal work. Welfare-to-work provision has no strong historical link with career guidance, and often includes elements of mandatory participation in jobseeking. Participants may not have access to supportive, non-directive and impartial career counselling of the kind that is freely available to university graduates. This generalisation must be tempered by acknowledging that the situation regarding adult guidance provision across the UK is complex and dynamic (Hughes, 2013).

The situation regarding services to young people is very different. Young people not in employment, education or training (NEET) have been targeted by public career guidance services since the late 1990s. Under the Connexions service in England strong targeting compromised the provision of a universal service (Watts, 2001), so middle to high income groups tended to be neglected. The issue continues to be a live one for the devolved 'all-age' services of Scotland, Wales and Northern Ireland, that must deploy finite resources while reconciling an espoused universalism with the targeting of disadvantaged youth. The Marmot review suggests a way out of this dilemma:

\footnotetext{
"Focusing solely on the most disadvantaged will not reduce health inequalities sufficiently.

To reduce the steepness of the social gradient in health, actions must be universal, but with a scale and intensity that is proportionate to the level of disadvantage. We call this proportionate universalism." (Marmot, 2010, p15).
}

\section{Do guidance services play a role in health selection?}

West (1991) specifically questions whether career services and other 'gatekeeper' agencies working at the transition from youth to adulthood are part of the process by which people with health conditions are selected for lower socio-economic positions, as a result of a failure to counter labour market pressures. Whilst such warnings are necessary, it is to be hoped that this is not the case. There is a long tradition of career guidance services providing additional support to young people with special needs in transition from school (McGinty \& Fish, 1992; Peck, 2004).

\section{How should career services respond to health inequality and is there anything they can do?}

In one sense, a focus on health inequalities simply strengthens the arguments of those, such as Ken Roberts, who have drawn attention to the impact of structural inequality on careers. It adds moral force (if any more were needed) to these arguments by pointing to the consequences for mortality and morbidity of low status. The issue of how to respond remains. Promoting gender equality, although 
desirable on its own terms, may make little impact on health inequality. Similarly promoting social mobility, also desirable on its own terms, is not sufficient to remove the health consequences of inequality, and may merely redistribute them. This line of argument could be extended to suggest that the career guidance profession should resort to a response based on a radical class consciousness. Such a position may be neither practical in the current political environment (Roberts, 2005) or without negative consequences (Watts, 1996). Roberts remains sceptical about the career guidance profession's potential to make any impact on social inequality:

"Thus class is destined to remain a troublesome topic for career advisers: one which some feel their pursuit of justice requires them to address but which, as a matter of fact, they are professionally incapacitated from tackling." (Roberts, 2005, p130).

This accusation of impotence may be overstated. Drawing on career theory, it is possible to construct a sound rationale underpinning the claim that employment support interventions may have positive effects on mental health (Robertson, 2013a). From a perspective of contemporary career theory several approaches seek to reconcile the importance of social structures with the possibility of human agency. An example is the 'careership' theory of Hodkinson \& Sparkes (1997). Their work is directly influenced by Bourdieu, and points to the possibility that career guidance might help an individual to redefine their horizons for action.

From a policy perspective, the Marmot review (2010) identifies six policy objectives that will reduce the social inequality that drives poor health outcomes, and two of these relate to directly careers work:

Policy Objective B: Enable all children, young people and adults to maximise their capabilities and have control over their lives

Policy objective C: Create fair employment and good work for all

These recommendations specifically include providing active labour market programmes (ALMPs) to enable disadvantaged groups to access good quality work, and support for young people to access education and training. Here we have an authoritative public health source asserting that such services are likely to have an impact.

From an empirical perspective, there is emerging evidence that ALMPs may ameliorate the negative health effects resulting from the potential intensification of social inequality during recession. Using suicide rates, a key mental health indicator for which clear data is available, Stuckler and Basu (2013) present evidence that where governments have chosen economic stimulus and strengthened social protection measures, they can completely avoid the detrimental effects on suicide rates associated 
with recession. Crucially they argue that ALMPs are one of the most cost effective measures governments can take in this regard:

“...we found that ALMPs had the greatest and most significant preventive effects on suicide when compared to other social protection programs. We estimated that, if done properly, ALMPs could neutralise the suicide risk of a recession...if executed well (i.e. in the Swedish style), ALMPs would essentially pay for themselves by boosting employment and reducing the burden on social welfare." (Stuckler \& Basu, 2013, pp117/119).

They argue that programmes for unemployed job seekers protect health by getting people into work (thus avoiding the health detriments of unemployment), by providing support, and also reduce stress in the employed by offering reassurance that job loss is not catastrophic. Services supporting potential job seekers cannot act at a macro level to influence the demand for labour (an important concern neglected by Stuckler and Basu), but they may impact on the supply of labour. A case can be made that career guidance provides added value to ALMPs: strengthening confidence and resilience through emotional support, empowerment and consideration of long term life planning. Career guidance services may potentially contribute not only to sustainable economic growth, but also to the promotion of public health (Robertson, 2013b). This is most likely to be effective within a wider context of harmonious policy initiatives.

\section{Summary and conclusions}

There is overwhelming evidence that socio-economic status is a key determinant of health outcomes. Work and education play a central role in establishing social status, security and income, which are key drivers of health outcomes. Whilst allowing for some reverse causality, socio-economic inequality in careers results in unequal health outcomes, an issue not yet fully recognised in the literature adopting structural explanations of career patterns. The restructuring of work in recent years appears to have reinforced socio-economic inequality, making these concerns more pressing. Irving (2005) locates social justice as central to the function of career education and guidance. If this is the case, then there is at the very least an argument for debating the implications of health inequality for careers and career guidance.

\section{References}

Acheson, D. (1998). Independent inquiry into inequalities in health: report. London: Stationery Office.

Arber, S. (1997). Comparing inequalities in women's and men's health, Social Science and Medicine, 44, 6, 773-787.

Attwood, K., Colditz, G.A. \& Kawachi, I. (1997). From public health science to prevention policy: placing science in its social and political contexts. American Journal of Public Health, 87, 10, 1603-1606.

Bambra, C. (2011). Work, worklessness and the political economy of health. Oxford: Oxford University Press.

Bambra, C., Smith, K.E., Garthwaite, K.E. \& Hunter, D.J. (2011). A labour of Sisyphus? Public 
policy and health inequalities research from the Black and Acheson reports to the Marmot review. Journal of Epidemiology and Community Health, 65, 5, 399-406.

Barnett, K., Mercer, S. W., Norbury, M., Watt, G., Wyke, S., \& Guthrie, B. (2012). Epidemiology of multimorbidity and implications for health care, research, and medical education: a cross-sectional study. The Lancet, 380 (9836), 37-43.

Bartley, M., Ferrie, J. \& Montgomery, S.M. (2006). Health and labour market disadvantage: unemployment, non-employment, and job insecurity. In: M. Marmot \& R.G. Wilkinson (Eds.) Social determinants of health. Oxford: Oxford University Press, pp78-96.

Black, C. (2008). Working for a healthier tomorrow: Dame Carol Black's review of the health of Britain's working age population. London: TSO.

Black, D. (1980). Inequalities in health: Report. London: Department of Health and Social Security.

Blane, D., Smith, G.D. \& Bartley, M. (1993). Social selection: what does it contribute to social class differences in health? Sociology of Health and Illness, 15, 1-15.

Blustein, D.L. (2006). The psychology of working: a new perspective for career development, counselling and public policy. Mahwah, NJ: Lawrence Erlbaum.

Broom, D.H., D’Souza, R.M., Strazdins, L., Butterworth, P., Parslow, R. \& Rodgers, B. (2006). The lesser evil: bad jobs or unemployment? A survey of mid-aged Australians. Social Science \& Medicine, 63, 3: 575-586.

Calhoun, C. (2000). Pierre Bourdieu. In: Ritzer, G. (Ed.) The Blackwell companion to major social theorists. Oxford: Blackwell, pp696-730.

Candy, B., Cattell, V., Clark, C. \& Stansfeld, S.A. (2007). The health impact of policy interventions tackling the social determinants of common mental disorder. Journal of Public Mental Health, 6, 2: 28-39.

Centre for Research into the Wider Benefits of Learning (2006). The wider benefits of learning: $a$ synthesis of findings from the centre for research on the wider benefits of learning 1999-2006. London: Department for Education \& Skills, DfES Research Brief RCB05-06.

Chadwick, E. (1842/1965). Report on the sanitary conditions of the labouring population of Gt Britain. Edinburgh: Edinburgh University Press.

Department for Work and Pensions (2008). Improving health and work: changing lives. The Government's response to Dame Carol Black's review of the health of Britain's working-age population. London: DWP/Department of Health.

De Vogli, R., Ferrie, J.E., Chandola, T., Kivimäki, M. \& Marmot, M.G. (2007). Unfairness and health: evidence from the Whitehall II study. Journal of Epidemiology and Community Health 2007; 61:513-518.

Dooley, D. (2003). Unemployment, underemployment, and mental health: conceptualising employment status as a continuum. American Journal of Community Psychology 32, 9-21.

Dorling, D. (2013) Unequal health: the scandal of our times. Bristol: The Policy Press.

Dorling, D. \& Thomas, B. (2011). Mapping inequalities in Britain, Sociology Review, 21, 1, 15-19.

Engels, F. (1845/1987). The condition of the working class in England, Harmondsworth: Penguin Press.

Ferrie, J.E., Shipley, M.J., Stansfeld, S.A.\& Marmot, M.G. (2002). Effects of chronic job insecurity and change in job security on self-reported health, minor psychiatric morbidity, physiological measures, and health related behaviours in British civil servants: the Whitehall II study. Journal of Epidemiology and Community Health, 56: 450-454.

Friedland, D.S., \& Price, R.H. (2003). Underemployment: consequences for the health and well-being of workers. American Journal of Community Psychology, 32, 1-2: 33-45.

Friedli, L. (2009). Mental health, resilience and inequalities. Copenhagen: World Health Organisation.

Furlong, A. (2002). Youth transitions and health: a literature review. Edinburgh: Health Education Board for Scotland.

Furlong, A. (2009). Revisiting transitional metaphors: reproducing inequalities under the conditions of late modernity. Journal of Education and Work, 22, 5, 343-353.

Giddens, A. (2009). Sociology. $6^{\text {th }}$ edition. Cambridge: Polity Press.

Gray, A.M. (1982). Inequalities and health. The Black report: a summary and comment. International Journal of Health Services, 12, 349-378.

Green, R. (2000). Unemployment, Perspectives and Policies. International journal of manpower. 21, 5, 338342.

Hart, J.T. (1971). Inverse care law. The Lancet, 297, 7696, February 27 $7^{\text {th }}$ 405-412.

Hammond, C. (2004). The impacts of learning on well-being, mental health and effective coping. In: T. Schuller, J. Preston, C. Hammond. \& A. Brassett-Grundy. The benefits of learning: the impact of education on health, family life and social capital. London: RoutledgeFalmer, pp37-56.

Hodkinson, P. \& Sparkes, A.C. (1997). Careership: a sociological theory of career decision making. British Journal of the Sociology of Education, 18, 1, 29-44. 
Hughes, D. (2010a). Social mobility of young people and adults in England: the contribution and impact of high quality careers services. Careers England.

Hughes, D (2010b). A literature review: social mobility and careers service policies. Careers England. Retrieved from: http://www.careersengland.org.uk/Documents/Public/DiscussionDocs/Careers\%20England\%20Literature\%2 OReview\%20Final\%20Paper\%20130510.pdf

Hughes, D. (2013). The changing UK careers landscape: tidal waves, turbulence and transformation. British Journal of Guidance and Counselling, 41, 3, 226-239.

Irving, B. (2005). Social justice: a context for career education and guidance. In: B. Irving \& B. Malik (Eds.) Critical reflections on career education and guidance: promoting social justice within a global economy. London: Routledge, pp. 10-24.

Karasek, R.A. (1979). Job Demands, Job Decision Latitude, and Mental Strain: Implications for Job Redesign, Administrative Science Quarterly, 24, 2, pp. 285-308

Lenard, P.T. \& Straehle, C. (2012). Introduction. In: P.T. Lenard \& C.Straehle, (Eds.) Health inequalities and global justice. Edinburgh: Edinburgh University Press, pp1-13.

Levitas, R. (1998). The inclusive society: social exclusion and New Labour. Basingstoke: MacMillan

Lindsay, C. \& Houston, D. (2011). Fit for purpose? Welfare reform and challenges for health and labour market policy in the UK, Environment and Planning, 43, 703-721.

Llena-Nozal, A. (2009). The effect of work status and working conditions on mental health in four OECD countries. National Institute Economic Review, 209, 1: 72-87.

Marmot, M., Rose, G., Shipley, M. \& Hamilton, P.J. (1978). Employment grade and coronary heart disease in British civil servants. Journal of Epidemiology and Community Health, 32, 244-249.

Marmot, M. (2010). Fair society, healthy lives: strategic review of health inequalities in England post 2010. London: The Marmot Review. Retrieved from: www.marmotreview.org

Marmot, M., Siegrest, J. \& Theorell, T. (2006). Health and the psycho-social environment at work. In: M. Marmot \& R.G. Wilkinson (Eds.) Social determinants of health. Oxford: Oxford University Press, pp97130.

McGinty, J. \& Fish, J. (1992). Learning support for young people in transition: leaving school for further education or work. Buckingham: Open University Press.

Mirowsky, J. \& Ross, C.E. (2003). The social causes of psychological distress. New York: Walter de Gruyter.

Muenning, P. (2007). Consequences in health status and costs. In C.R. Belfield \& H.M. Levin (Eds.) The price we pay: economic and social consequences of inadequate education. Washington, D.C: Brookings Institution Press. pp. 125-141.

Muntaner, C., Ng, E., Vanroelen, C., Christ, S. \& Eaton, W.W. (2013). Social stratification, social closure, and social class as determinants of mental health disparities. In: C.S. Anelhensel, J.C. Phelan \& A. Bierman (Eds.) Handbook of the Sociology of Mental Health, pp205-227. Springer.

Murali, V. \& Oyebode, F. (2004). Poverty, social inequality and mental health. Advances in Psychiatric Treatment, 10, 216-224.

Nazroo, J.Y. (2003). The structuring of ethnic inequalities in health: economic position, racial discrimination and racism. American Journal of Public Health, 93, 2, 277-284.

Pearce, J. (2013). Geographies of health inequality. In Cockerham WC, Dingwall R, Quah SR, (Eds.), The Wiley-Blackwell encyclopedia of health, illness, behavior, and society, Forthcoming. Wiley-Blackwell.

Pearce, J. (2012). The 'blemish of place': stigma, geography and health inequalities, Social Science and Medicine 75, 1921-1924.

Pearce, J., Richardson E.A., Mitchell R.J., Shortt, N.K., (2010). Environmental justice and health: The implications of the socio-spatial distribution of multiple environmental deprivation for health inequalities in the United Kingdom, Transactions of the Institute of British Geographers, 35, 522-539.

Peck, D. (2004). Careers Services: history, policy and practice in the United Kingdom, London: RoutledgeFarmer.

Roberts, K. (1977). The social conditions and limitations of guidance. British journal of guidance and counselling, 5, 1, 1-9.

Roberts, K. (1997). Prolonged transitions to uncertain destinations: the implications for career guidance. British Journal of Guidance and Counselling, 25, 3: 345-360.

Roberts, K. (2002). Right approach for the wrong reason. In: Institute of Career Guidance, Constructing the future, Stourbridge: ICG, pp 1-9.

Roberts, K. (2005). Social class, opportunity structures and career guidance. In: B. Irving \& B. Malik (Eds.) Critical reflections on career education and guidance: promoting social justice within a global economy. London: Routledge, pp 130-142.

Robertson, P.J. (2013a). The well-being outcomes of career guidance. British Journal of Guidance and Counselling, 41, 3, $254-266$. 
Robertson, P.J. (2013b). Career guidance and public mental health. International Journal for Educational and Vocational Guidance, 13, 2, 151-164.

Rogers, A. \& Pilgrim, D. (2003). Mental health \& inequality. London: Palgrave Macmillan.

Ross, C.E. \& Mirowsky, J. (1999). Refining the association between education and health: the effects of quantity, credential and selectivity. Demography, 36, 4: 445-460.

Sacker, A., Firth, D., Fitzpatrick, R. Lynch, K. Bartley, M. (2000). Comparing health inequality in men and women: prospective study of mortality 1986-96. British medical journal, 320, 1303-1307.

Sapolsky, R. (2005). Sick of Poverty. Scientific American. December: 73-79.

Shaw, M. \& Dorling, D. (2004). Who cares in England and Wales? The positive care law: a cross sectional study. British Journal of General Practice, 54, 899-903.

Shildrick, T., MacDonald, R., Webster, C. \& Garthwaite, K. (2012). Poverty and insecurity: life in low pay, no pay Britain. Bristol: the Policy Press.

Siegrest, J. \& Theorell, T. (2006). Socio-economic position and health: the role of work and employment. In: J. Siegrest \& M. Marmot (Eds.) Social inequalities in health: new evidence and policy implications. Oxford: Oxford University Press, pp73-100.

Smith, G.D., Dorling, D. \& Shaw, M. (2001). Introduction in: G. D. Smith, D.Dorling, \& M. Shaw (Eds.) Poverty, inequality and health in Britain, 1800-2000: a reader. Bristol: The Policy Press, pp xi-lxxxvii.

Standing, G. (2011). The precariat: The new dangerous class. London: Bloomsbury.

Stansfeld, S.A., Fuhrer, R., Shipley, M.J. \& Marmot, M.G. (1999). Work characteristics predict psychiatric disorder: prospective results from the Whitehall II study. Occupational and Environmental Medicine, 56, 5: 302-307.

Steptoe, A. (2006). Psychobiological processes linking socio-economic position with health. In: J. Siegrest \& M. Marmot (Eds.) Social inequalities in health: new evidence and policy implications. Oxford: Oxford University Press, pp101-126.

Stiglitz, J. E. (2013). The price of inequality. London: Penguin.

Stoate, H. \& Jones, B. (2010). Work, the grand cure: how changing the way Britain works will be good for our health. London: The Fabian Society.

Stuckler, D. \& Basu, S. (2013). The body economic: why austerity kills. London: Allen Lane.

Šverko, B., Galić, Z., Seršić, D.M \& Galšeić, M. (2008). Working in the hidden economy: associations with the latent benefits and psychological health. European Journal of Work and Organisational Psychology, 17, 3, 301-314.

The Equality Trust (2010). The authors respond to questions about the spirit level's analysis London: The Equality Trust. Retreived from: http://www.equalitytrust.org.uk/resources/response-to-questions/

The Panel on Fair Access to the Professions (2009). Unleashing aspiration: the final report of the panel on fair access to the professions. London: Cabinet Office

Thomas, B., Dorling, D. \& Smith, G.D. (2010). Inequalities in premature mortality in Britain: observational study from 1921 to 2007, British Medical Journal, 341, c3639.

Tudor Hart, J. (1971). The inverse care law, The Lancet, 27 February, 406-12.

Vyas, M.V., Garg, A.X., Iansavichus, A.V., Costella, J., Donner, A., Laugsand, L.E., Janszky, I., Mrkobrada, M., Parraga, G., Hackam, D.G. (2012). Shift work and vascular events: systematic review and metaanalysis, British Medical Journal, 345:e4800.

Wardle, J. \& Steptoe, A. (2005). Public health psychology. The Psychologist, 18,11, 672-675.

Watson, T.J. (2008). Sociology, work and industry. (5 ${ }^{\text {th }}$ ed.), London: Routledge.

Watts, A.G. (1996). Socio-political ideologies in guidance. In: A.G. Watts, B. Law, J. Killeen, J.M. Kidd \& R. Hawthorn: Rethinking career education and guidance. London: Routledge.

Watts, A. G. (2001). Career guidance and social exclusion: A cautionary tale. British Journal of Guidance and Counselling, 29(2), 157-176.

West, P. (1991). Rethinking the health selection explanation for health inequalities, Social Science and Medicine, 32, 372-384.

Willis, P.E. (1977). Learning to labour: how working class kids get working class jobs. Aldershot: Gower.

Wilkinson, R.G. (1997). Health inequalities: relative or absolute material standards. British MedicalJjournal, 314, 591-595.

Wilkinson, R.G. \& Pickett, K.E. (2006). Income inequality and population health. Social Science and Medicine, 62, 1768-1784.

Wilkinson, R.G. \& Pickett, K.E. (2007). The problem of relative deprivation: why some societies do better than others. Social Science and Medicine, 65, 1965-1978.

Wilkinson, R. \& Pickett, K. (2010). The spirit level: why equality is better for everyone. (2nd edition). London: Penguin.

Woodward, A. \& Kawachi, I. (2000). Why reduce health inequalities? Journal of Epidemiology and Community Health, 54, 923-929. 
World Health Organisation (2007) Employment conditions and health inequalities: Final report to the WHO Commission on social determinants of health. Geneva: WHO

World Health Organization (2008). Final report: Closing the gap in a generation: health equity through action on the social determinants of health. Final Report of the Commission on Social Determinants of Health. Geneva, WHO/CSDH. 